\title{
$\begin{array}{ll}\text { Research Square } & \text { Preprints are preliminary reports that have not undergone peer review. } \\ \text { They should not be considered conclusive, used to inform clinical practice, }\end{array}$ or referenced by the media as validated information. \\ Prevalence and risk factors of psychological impacts among the quarantined population during the COVID-19 pandemic in China
}

\section{Bin Yan}

The First Affiliated Hospital of Shenzhen University

Yeen Huang ( $\sim 743159984 @ q q . c o m)$

Keller Graduate School of Management of DeVry University

\section{Research article}

Keywords: COVID-19; psychological impact; anxiety; depressive; sleep

Posted Date: April 28th, 2020

DOI: https://doi.org/10.21203/rs.3.rs-17172/v2

License: (ㅇ) (1) This work is licensed under a Creative Commons Attribution 4.0 International License. Read Full License 


\section{Abstract}

Background: The Corona Virus Disease 2019 (COVID-19) pandemic has swept into over 200 countries with considerable confirmed cases and deaths, and has caused public panic and mental health stress. We aimed to examine the quarantined population's psychological problems during the pandemic, and to explore the potential risk factors.

Methods: From 3 February, to 17 February, 2020, we conducted a web-based cross-sectional survey to collect data from 6,961 participants assessed with demographic data, knowledge about the COVID-19, anxiety disorders, depressive symptoms, and poor sleep. Multivariate logistic regressions were used to identify the risk factors associated with the psychological issues.

Results: The overall prevalence of anxiety disorders, depressive symptoms, and poor sleep quality were $34.6 \%$, $19.2 \%$, and $18.3 \%$, respectively. People aged $<35$ years reported a higher prevalence of anxiety disorders and depressive symptoms than people aged $\geq 35$ years $(P<0.01)$. Compared with other occupational groups, healthcare workers had the highest rate of poor sleep quality $(P<0.001)$. Younger age, spent $\geq 3$ hours a day focusing on the pandemic, and healthcare workers were the potential risk factors for psychological problems.

Conclusions: During the COVID-19 pandemic, the quarantined population showed a severe psychological impact, especially people aged $<35$ years, those spent $\geq 3$ hours a day focusing on the pandemic, and being a healthcare worker. Our findings can be a helpful reference for intervention and prevention programs for the quarantined population facing crisis in the future.

\section{Background}

Since the beginning of December 2019, the Chinese city of Wuhan has reported a novel pneumonia caused by the Corona Virus Disease 2019 (COVID-19), which is a cluster of acute respiratory illnesses with unknown causes, and is rapidly spreading domestically and internationally [1-3]. Patients with the disease may developed severe pneumonia, pulmonary oedema, or even multiple organ failure and have died. On March 11, the World Health Organization (WHO) declared the COVID-19 outbreak could be characterized as a pandemic due to the virus spreads increasingly worldwide [4]. As of April 14, 2020, the COVID-19 pandemic has swept into 200 countries with more than 1.8 million confirmed cases and 117,217 deaths. According to data released by the National Health Commission of China, a total of 83,745 cases have been confirmed, and 3,352 people died from the illness.[5].

With the further understanding of the epidemiological characteristics of the COVID-19, China government confirmed that the Severe Acute Respiratory Syndrome Coronavirus 2 (SARS-CoV-2) could be spread from human to human in the early stages of disease development. At the same time, several healthcare workers in Wuhan have been reported to be infected [6]. Since then, the COVID-19 has caused public panic and mental health stress, causing a significant shortage of medical masks and alcohol across the country, and a large number of people rushed to pharmacies overnight to buy the so-called "special effect drugs" [7]. Facing this critical situation, overwhelming workload, widespread media coverage, and feelings of being inadequately supported may all contribute to the mental health burden of healthcare workers. Much front-line medical staff work more than 16 hours a day on average, causing them to not get enough sleep. In Japan, a 37-year-old 
government worker who was in charge of isolated returnees from Wuhan was found to have died from apparent suicide [8].

The COVID-19 is a distinct clade from the betacoronaviruses related to human severe acute respiratory syndrome (SARS) and the Middle East respiratory syndrome (MERS) [9]. Previous studies showed that psychological impact could occur in both SARS survivors and healthcare workers during the SARS outbreak [1012]. Depressive symptoms were showed to be one of the most prevalent long-term psychological condition on the general population [13]. Similar results have also been reported in the previous research of MERS [14]. However, the current studies are still focus on identifying the epidemiological, clinical, or virological characteristics of the infected cases. To our knowledge, there are relatively scarce research examining the psychological impact on the COVID-19 on the quarantined population in China.

To address this gap, the aim of current study was to evaluate the mental health outcomes among the quarantined population by quantifying the levels of symptoms of anxiety, depression, and poor sleep, and by analyzing potential risk factors associated with these symptoms. This study aimed to provide an assessment of the psychological burden of the Chinese quarantined population, which could serve as important evidence to direct the promotion of mental health well-being among the quarantined population.

\section{Methods}

\section{Study design}

A web-based cross-sectional survey based on the National Internet Survey on Emotional and Mental Health (NISEMH) was used to collected data from participants regarding their demographic information, knowledge about the COVID-19, amount of time focusing on the COVID-19, and psychological impact. Our web-based survey of the COVID-19 was broadcasted on the Internet through the WeChat public platform and mainstream social platforms (such as Weibo, online forums, etc.). People using WeChat or other social tools may see our questionnaire request, and answered the survey by scanning the QR code of the questionnaire address or clicking the relevant link. This web-based questionnaire was completely voluntary and non-commercial.

\section{Participants}

The target population of this study are the quarantined population. We identified the participants through the following items: Which of the following identities best described your actual situation? (1) Not ill but quarantined; (2) Suspected infected; (3) Confirmed cases; or (4) Not sure. According to the purpose of our study, only subjects belonging to category (1) will be included in our analysis.

\section{Data collection and quality control}

In this study, participants answered the questionnaires anonymously on the Internet (via computer or smartphone) from February 3, 2020, to February 17, 2020. All subjects reported their demographic data, knowledge about the COVID-19 pandemic, and three standardized scales, which were used to evaluated their anxiety disorders, depressive symptoms, and sleep quality. To ensure the quality of the survey, we have set the response range of some items (e.g., the age range was limited to 18-80 years old, some items needed to be answered in reverse) and encouraged participants to answer carefully through questionnaire explanations. 
Furthermore, we restricted each electronic device to answer the survey once by identifying the unique IP address. Considering that a small number of voluntary participants may answer randomly or have difficulty understanding the items of our survey, questionnaires that were completed $<1$ minute or $>60$ minutes would be excluded from the analysis. Finally, a total of 6,961 participants who completed the questionnaires were included in our study.

\section{Psychological impacts}

\section{Anxiety disorders}

Chinese version of Generalized Anxiety Disorder-7 (GAD-7) scale was used to assess the individual's anxiety symptoms. The GAD-7 has been validated in the Chinese cultural context and has been previously used [15, 16]. Seven items assess the frequency of anxiety symptoms over the past two weeks on a 4-point Liker-scale ranging from 0 (never) to 3 (nearly every day). The total score of GAD-7 ranged from 0 to 21, with increasing scores indicating a more severe functional impairments as a result of anxiety symptoms [17]. In this study, we defined a GAD-total score $\geq 9$ points as the presence of anxiety disorders [15].

\section{Depressive symptoms}

We used the Center for Epidemiology Scale for Depression (CES-D) in the Chinese version to identify whether participants had showed a symptoms of depression [18], and the Chinese version of this scale has been validated and extensively utilized in the Chinese population $[18,19]$. Total of twenty items assess the frequency of depressive symptoms over the past 2 weeks on a 4-point Liker-scale ranging from 0 (rarely or none of the time) to 3 (most or all of the time). The score range of the CES-D is 0-60 points, and higher scores indicated a more severe depressive symptoms [20]. In this study, CES-D scores > 28 points indicated depressive symptoms.

\section{Poor sleep}

The Chinese version of the Pittsburgh Sleep Quality Index (PSQI) scale was used to evaluated the subject's sleep disorders over the past 2 weeks [21]. The PSQI scale contains seven components (subjective sleep quality, sleep duration, sleep latency, habitual sleep efficiency, use of sleep medications, sleep disturbance, and daytime dysfunction), and the score for each component ranging from 0 to 3 points. The global PSQI score ranges from 0 to 21, with higher scores indicated more a severe poor sleep [22]. The Chinese version of PSQI has been demonstrated to be reliable and valid in the Chinese population [21], a global PSQI score > 7 points indicated poor sleep quality.

\section{Demographic information}

Demographic data included gender, age, and individual occupations. Occupation included the following four types: (1) Healthcare workers, which included doctors, nurses, and health-related administrators; (2) Enterprise or institution workers, which consisted of enterprise employees, national/provincial/municipal institution workers, and other relevant staff; (3) Teachers or students, which included teachers or students from universities, middle schools, or elementary schools; and (4) Others, which consisted of freelancers, retiree, social worker, and other relevant staff. 
Times spent focusing on the COVID-19 pandemic was used to measure the average time (in hours) the participants spent focusing on the COVID-19 information each day, by asking the participants on: "How much time (in hours) do you spend focusing on the COVID-19 outbreak each day on average? (Including reading outbreak information on the TV news and/or mobile phone, discussing the progress of the outbreak with family or friends, etc.)".

\section{Knowledge about the COVID-19}

The knowledge about the COVID-19 pandemic was evaluated by the following 5 judgment questions:

1. Inhalation of droplets from sneezing, coughing, or talking of an infected person could cause infection;

2. Contact with something contaminated by an infected person could lead to infection; $c$. The incubation period of the virus does not exceed 14 days;

3. Contact with an asymptomatic person might also lead to infection;

4. There are already targeted drugs that could cure the disease.

Of the above 5 questions, one point was given for correct answers, and no points were given for incorrect or uncertain answers. Participants with scores equal to 5 points, equal to 4 points, and $\leq 3$ points were considered to be "Knowledgeable", "Generally knowledgeable", and "Not knowledgeable”.

\section{Statistical analysis}

First, descriptive analyses were conducted to describe the demographic characteristics and knowledge about the COVID-19 in the quarantined population. Second, the prevalence of anxiety disorders, depressive symptoms, and poor sleep stratified by gender, age, and occupations were reported, and the Chi-square test $\left(\chi^{2}\right)$ was used to compare the differences between groups. Third, univariate and multivariate logistic regression models were performed to explore the potential risk factors for psychological impact of the quarantined population. Odds ratio $(O R)$, adjusted odds ratio $(A O R)$, and $95 \%$ confidence interval $(95 \% C l)$ were obtained from logistic regression models. All data were analyzed using Statistical Package for Social Sciences (SPSS) version 24.0. $P$ values of less than 0.05 were considered statistically significant (2-sided tests).

\section{Results}

\section{Demographic characteristics of the quarantined population}

As shown in Table 1, of the 6,961 samples analyzed, 3188 (45.8\%) were males and 3,773 (54.2\%) were females, and the mean (standard deviation) age of the participants was $36.2 \pm 4.9$ years. Among these samples, 2,241 (32.2\%) of participants were healthcare workers, 3,032 (43.6\%) participants focused on the COVID-19 related information for 3 hours or more each day, and 5,442 (78.2\%) participants scored in the highest category "Knowledgeable" regarding COVID-19 knowledge.

\section{Prevalence of psychological impact among the quarantined population during the COVID-19 pandemic}

As shown in Table 1, the overall prevalence of anxiety disorders, depressive symptoms, and poor sleep quality was $34.6 \%, 19.2 \%$, and $18.3 \%$, respectively. Females reported a higher prevalence of anxiety disorders and 
depressive symptoms than males $(P<0.001)$. The prevalence of anxiety disorders and depressive symptoms were significantly higher in participants aged $<35$ years than in participants aged $\geq 35$ years $(P<0.01)$.

Compared with other occupational groups, healthcare workers $(23.6 \%)$ reported the highest rate of poor sleep quality $(P<0.001)$. Moreover, participants who spent $\geq 3$ hours a day focusing on the COVID-19 information had a significantly higher prevalence of psychological impact than those spent less time focusing on the pandemic $(P<0.001)$.

\section{Association of risk factors with psychological impact among the quarantined population during the COVID-19 pandemic}

The associations of risks factors with anxiety disorders, depressive symptoms, and poor sleep quality among the quarantined population during the COVID-19 pandemic were presented in Table 2. In the univariate logistic regression models, aged $<35$ years $(O R=1.57,95 \% \mathrm{Cl}$ : $1.32-2.05)$, occupation as a teacher or student $(O R=1.78$, $95 \%$ Cl. 1.03-3.07), and spent $\geq 3$ hours a day focusing on the pandemic ( $O R=1.95,95 \%$ Cl. 1.67-2.41) were significantly associated with anxiety disorder in the quarantined population. Moreover, aged < 35 years was associated with depressive symptoms ( $O R=1.70,95 \% \mathrm{Cl}$ : 1.31-2.19). Healthcare workers were at higher for poor sleep during the COVID-19 pandemic (OR=1.51, 95\% Cl: 1.18-2.12).

Furthermore, in the multivariate logistic regression models, the above associations have weakened but most of them were still statistical difference. Participants aged < 35 years were more likely to have anxiety disorders $(A O R=1.45,95 \% C l: 1.29-2.01)$ and depressive symptoms $(A O R=1.67,95 \% C l: 1.44-2.12)$ than those aged $\geq 35$ years. Participants who spent $\geq 3$ hours a day focusing on the COVID-19 were at higher risk for developing anxiety disorders than those spent less time focusing on the pandemic ( $A O R=1.68,95 \%$ Cl: 1.43-2.15). Compared with other occupation groups, healthcare workers were more likely to report poor sleep $(A O R=1.40$, $95 \%$ Cl. 1.16-1.91).

\section{Discussion}

This web-based cross-sectional survey enrolled 6,961 participants and revealed a high prevalence of mental health symptoms among the quarantined population in China. Overall, 34.6\%, 19.2\%, and 18.3\% of all participants reported symptoms of anxiety, depression, and poor sleep. Females, younger people, and healthcare workers reported more worse mental health outcomes. Our study further indicated that people aged $<35$ years, those spent $\geq 3$ hours a day focusing on the pandemic, and being a healthcare worker were associated with experiencing severe psychological impact. Together, our results present concerns about the psychological wellbeing of the quarantined population in the face of the COVID-19 pandemic.

In 2019, a national cross-sectional survey conduct by the China Mental Health Survey (CMHS) showed that about $5.0 \%$ and $3.6 \%$ of Chinese adults have symptoms of anxiety and depression during the past 12-month, respectively [23]. In this study, a significant proportion of participants experience psychological impact when the COVID-19 occurred. Our findings were similar to a previous study during the acute SARS outbreak [24], we found that one in three quarantined population showed anxiety symptoms, and this emotion was more pronounced among younger people and females, which was consistent with previous study that psychological symptoms were linked to younger age [24] and females [25]. Besides, nearly one in five quarantined population had symptoms of depression and poor sleep. The psychological response of the quarantined population to a 
pandemic of infectious diseases may be complicated. Sources of stress may include spread of virus, feeling of vulnerability or loss of control and concerns about health of self, changes in daily life and work, and being isolated [26]. Actually, the fact that the COVID-19 is confirmed to be transmitted from human to human, and associated with high morbidity and potentially fatal may intensify the pressures and concerns of the quarantined population.

Furthermore, we found that aged $<35$ years and those spent $\geq 3$ hours a day focusing on the pandemic may be potential risk factors for the psychological impact of the quarantined population. People aged < 35 years were more likely to develop anxiety and depressive symptoms than those aged $\geq 35$ years. Our results were similar to those of a previous study in Taiwan during the SARS outbreak [24]. Moreover, quarantined people who spent $\geq 3$ hours a day focusing on the COVID-19 were at higher risk for developing anxiety disorders than those spent less time focusing on the pandemic. The possible manifestation of this panic mood for isolated individuals may be related to the body's normal protective response to the pressure in the face of the crisis [27].

During the SARS and MERS outbreak, several studies conducted in hospital workers showed that medical staff were at high risk for developing psychological distress [11, 12,14]. A recent study conducted in the times of COVID-19 outbreak showed that healthcare workers experiencing severe symptoms of insomnia [28]. Consistent with the previous research, our findings showed that nearly one in four healthcare workers have sleep problems, being a healthcare workers may be an independent risk factor for the poor sleep. This may related to the increased working intensity and time of healthcare workers in the face of high mortality infectious disease outbreaks (such as SARS and MERS), causing them not having enough time to rest, and vulnerable to chronic pressure and poor sleep quality [29].

As the COVID-19 pandemic continues to spread, our findings will provide important guideline for developing an effective psychological intervention in China. This study has some public health and policy implications. First, national health administration needs to identify the high-risk quarantined population (such as females, younger people, and healthcare workers) based on sociodemographic information for providing early psychological assistance. Health authorities could consider providing web-based psychological interventions (e.g., cognitive behavior therapy) and psychoeducation to reduce risk of virus transmission. Second, government and health agencies need to provide correct health information during the pandemic to reduce the impact of rumors. National public health organization should establish a uniform, official, integrated psychological counseling platform to provide mental health counseling to isolated people in need. Third, try to control the time of receiving pandemic information less than two hours a day and balance individual's spare time with other activities (e.g., meditation or exercise at home), avoid receiving too many rumors and focus only on the facts and data of the pandemic. Fourth, maintain individual's sleep habits as much as possible, and do not pay too much attention to outbreak information before going to sleep.

Several limitations should be note when interpreting our findings. First, the data and relevant analyses presented here were derived from a cross-sectional design, it is difficult to make causal inferences. Second, the study was limited to COVID-19 pandemic, leading to the sampling of this study was voluntary and conducted by online survey. Therefore, the possibility of the selection bias should be considered, which may be caused overestimating the prevalence of psychological problems because people who voluntarily choose to participate in the survey may be more aware of their mental health issues than those who did not participate. Third, selfreported levels of psychological impact may not always be aligned with assessment by mental health 
professionals. Fourth, because our research was based on an online survey and the data come from volunteers, the representativeness of the sample cannot be guaranteed, and the study population might not reflect the actual pattern of the isolated population, which may affect the external validity of our findings.

\section{Conclusion}

The present study identified the prevalence of psychological impacts for the quarantined population during times of crisis, and the risk was increased in young people, people who spent too much time focusing on the pandemic, and the medical staff. There should be more awareness regarding the quarantined population as targets for mental health services, and prompt and continuous psychological intervention for pandemic preparedness. This would be enhancing crisis-control measures and psychological care in the face of a future comparable infectious disease pandemic.

\section{Author Statement Contributors:}

Ning Zhao conceptualized and designed the study, review and revised the manuscript, and approved the final manuscript as submitted. Yeen Huang designed the data collection instruments, coordinated and supervised data collection, carried out the initial analyses, and interpreted the data, drafted the initial manuscript, and approved the final manuscript as submitted. Ning Zhao and Yeen Huang agree to be accountable for all aspects of the study.

\section{Abbreviations}

COVID-19: 2019 Corona Virus Disease; GAD: Generalized Anxiety Disorder; CES-D: Center for Epidemiology Scale for Depression; PSQI: Pittsburgh Sleep Quality Index; WHO: World Health Organization; PHEIC: Public Health Emergency of International Concern; SARS: Severe Acute Respiratory Syndrome; MERS: Middle East Respiratory Syndrome; PTSD: Post-Traumatic Stress Disorder; NISEMH: National Internet Survey on Emotional and Mental Health; OR: Odds Ratio; AOR: Adjusted Odds Ratio; Cl: Confidence Interval; SD: Standard Deviation; SPSS: Statistical Package for Social Sciences;

\section{Declarations}

\section{Author statement contributors:}

Yeen Huang conceptualized and designed the study, review and revised the manuscript, and approved the final manuscript as submitted. Bin Yan designed the data collection instruments, coordinated and supervised data collection, carried out the initial analyses, and interpreted the data, drafted the initial manuscript, and approved the final manuscript as submitted. Yeen Huang and Bin Yan agree to be accountable for all aspects of the study.

\section{Funding:}

Not applicable. 
The authors would like to thank all the participants in our study. In addition, we express our heartfelt respect to all healthcare workers who are fighting the pandemic on the front line. Finally, we thank Ms. Qiaohong Chen for providing professional language help.

\section{Availability of data and materials}

The questionnaire and datasets used and analyzed during this study are available from the corresponding authors upon reasonable request.

\section{Ethics approval and consent to participate:}

This study was conducted in accordance with the Declaration of Helsinki, and was approved by the Ethics Committee of the First Affiliated Hospital of Shenzhen University. Electronic informed consent was obtained from each participant prior to starting the investigation. Participant could withdraw from the survey at any moment without providing any justification.

\section{Competing interests:}

None.

\section{Consent for publication:}

Not applicable.

\section{References}

1. Wuhan Municipal Health Commission. Report of novel coronavirus-infected pneumonia in China. Published January 20, 2020. Accessed January 31, 2020.

http://wjw.wuhan.gov.cn/front/web/showDetail/2020012009077

2. Paules, C.I., Marston, H.D., Fauci, A.S. Coronavirus infections-more than just the common cold: JAMA. Published online January 23, 2020. doi:10.1001/jama.2020.0757

3. Wang, D., Hu, B., Hu, C., et al. Clinical characteristics of 138 hospitalized patients with 2019 novel coronavirus-infected pneumonia in Wuhan, China. JAMA. Published online February 7, 2020. doi:10.1001/jama.2020.1585

4. World Health Organization. Situation report-51. Accessed April 15, 2020. https://www.who.int/docs/defaultsource/coronaviruse/situation-reports/20200311-sitrep-51-covid-19.pdf?sfvrsn=1ba62e57_10

5. National Health Commission of the People's Republic of China. News: The latest situation of the new coronavirus pneumonia epidemic situation as of 24:00 on April 14. Accessed April 15, 2020. http://www.nhc.gov.cn/xcs/yqfkdt/202004/35d096269e2848cdb4d3cb38e4c6bd1b.shtml

6. XINHUANET. The Latest: China confirms human-to-human transmission of 2019-nCoV, infections among medical staff. Accessed January 21, 2020. http://www.xinhuanet.com/english/202001/21/c_138722888.htm

7. People's daily of China. The novel coronavirus can be inhibited by Chinese patent medicine Shuanghuanglian oral liquid. Accessed January 31, 2020. 
http://search.people.com.cn/cnpeople/news/getNewsResult.jsp

8. The Japan Times. Japanese official looking after Wuhan returnees found dead. Accessed February 3, 2020. https://www.japantimes.co.jp/news/2020/02/02/national/crime-legal/japanese-official-looking-wuhanreturnees-found-dead/.

9. Zhu, N., Zhang, D., Wang, W., et al. A novel coronavirus from patients with pneumonia in China, 2019. N Engl J Med. Published online January 24, 2020. doi: 10.1056/NEJMoa2001017

10. Lee, A.M., Wong, J.G., McAlonan, G.M., et al. Stress and psychological distress among SARS survivors 1 year after the outbreak. Can J Psychiatry. 2007. 52; 233-240. doi: 10.1177/070674370705200405

11. Lu, Y.C., Shu, B.C., Chang, Y.Y., Lung, F.W. The mental health of hospital workers dealing with severe acute respiratory syndrome. Psychother Psychosom. 2006. 75; 370-375. doi: 10.1159/000095443

12. McAlonan, G. M., Lee, A.M., Cheung, V., et al. Immediate and sustained psychological impact of an emerging infectious disease outbreak on health care workers. Can J Psychiatry. 2007. 52; 241-247. doi:

$10.1177 / 070674370705200406$

13. Mak, I.W., Chu, M.C., Pan, P.C., Yiu, M.G., Chan, V.L. Long-term psychiatric morbidities among SARS survivors. Gen Hosp Psychiatry. 2009. 31; 318-326. doi: 10.1016/j.genhosppsych.2009.03.001

14. Lee, S.M., Kang, W.S., Cho, A.R., Kim, T., Park, J.K. Psychological impact of the 2015 MERS outbreak on hospital workers and quarantined hemodialysis patients. Compr Psychiatry. 2018. 87; 123-127. doi: 10.1016/j.comppsych.2018.10.003

15. Wang, Y., Chen, R., Zhang, L. Reliability and validity of generalized anxiety scale-7 in inpatients in Chinese general hospital. J Clin Psychiatr. 2018. 28; 168-171. doi: 10.3969/j.issn.1005-3220.2018.03.007

16. Tong, X., An, D., McGonigal, A., Park, S.P., Zhou, D. Validation of the Generalized Anxiety Disorder-7 (GAD-7) among Chinese people with epilepsy. Epilepsy Res. 2016. 120; 31-36. doi:

10.1016/j.eplepsyres.2015.11.019

17. Spitzer, R.L., Kroenke, K., Williams, J.B., Lowe, B. A brief measure for assessing generalized anxiety disorder: the GAD-7. Arch Intern Med. 2006. 166; 1092-1097. doi: 10.1001/archinte.166.10.1092

18. Zhang, J., Wu, Z.Y., Fang, G., Li, J., Han, B.X., Chen, Z.Y. Establishing a national urban norm for the Center for Epidemiology Scale for Depression. Chin Ment Health J. 2010. 24; 139-143. doi: 10.3969/j.issn.10006729.2010.02.015

19. Zhang, B.S., Li, J. Reliability and validity of the simplified version of the Center for Epidemiology Scale for Depression in the national adult population. Chin Ment Health J. 2011. 25; 506-511. doi: 10.3969/j.issn.1000-6729.2011.07.007

20. Radloff, L.S. The CES-D scale: A self-report depression scale for research in the general population. Appl Psychol Meas. 1977. 1; 385-401. doi: 10.1177/014662167700100306

21. Liu, X.C., Tang, M.Q., Hu, L., et al. Reliability and Validity of Pittsburgh Sleep Quality Index. J Chin Psychiatry. 1996. 29; 103-107. doi: 10.1007/BF02951625

22. Buysse, D.J., Reynolds, C.R., Monk, T.H., Berman, S.R., Kupfer, D.J. The Pittsburgh Sleep Quality Index: a new instrument for psychiatric practice and research. Psychiatry Res. 1989. 28; 193-213. doi: 10.1016/01651781(89)90047-4

23. Huang, Y., Wang, Y., Wang, H., et al. Prevalence of mental disorders in China: A cross-sectional epidemiological study. Lancet Psychiatry. 2019. 41; 211-224. https://doi.org/10.1016/S2215- 
0366(18)30511-X

24. Su, T.P., Lien, T.C., Yang, C.Y., et al. Prevalence of psychiatric morbidity and psychological adaptation of the nurses in a structured SARS caring unit during outbreak: a prospective and periodic assessment study in Taiwan. J Psychiatr Res. 2007. 41; 119-130. doi: 10.1016/j.jpsychires.2005.12.006

25. Guo, X., Meng, Z., Huang, G., et al. Meta-analysis of the prevalence of anxiety disorders in mainland China from 2000 to 2015. Sci Rep. 2016. 6; 28033. doi: 10.1038/srep28033

26. Wong, T.W., Yau, J.K., Chan, C.L., et al. The psychological impact of severe acute respiratory syndrome outbreak on healthcare workers in emergency departments and how they cope. Eur J Emerg Med. 2005. 12; 13-18. doi:10.1097/00063110-200502000-00005

27. Maunder, R., Hunter, J., Vincent, L., et al. The immediate psychological and occupational impact of the 2003 SARS outbreak in a teaching hospital. CMAJ. 2003. 168; 1245-1251. doi: doi:10.1001/jama.289.18.2432

28. Lai, J.B., Ma, S.M., Wang, Y., et al. Factors associated with mental health outcomes among health care workers exposed to Coronavirus Disease 2019. JAMA Netw Open. 2020. 3; e203976. doi:10.1001/jamanetworkopen.2020.3976

29. Chen, R., Chou, K.R, Huang, Y.J., et al. Effects of a SARS prevention programme in Taiwan on nursing staff's anxiety, depression and sleep quality: A longitudinal survey. Int J Nurs Stud. 2006. 43; 215-225. doi: 10.1016/j.ijnurstu.2005.03.006.

\section{Tables}

Table 1. Demographic characteristics and prevalence of psychological impact among the quarantined population during the COVID-19 pandemic $(\mathrm{N}=6,961)$.

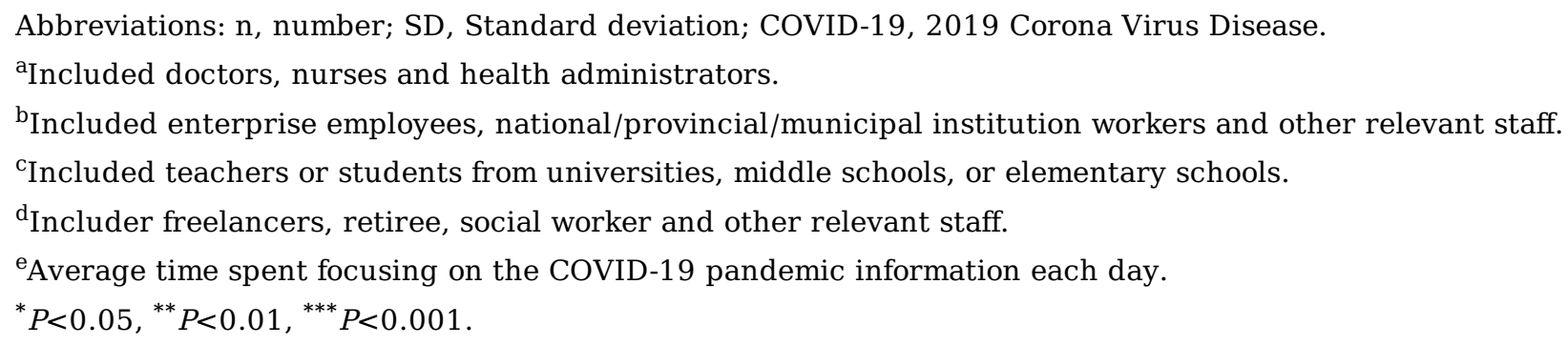

Table 2. Association of risk factors with psychological impact among the quarantined population during the COVID-19 pandemic $(\mathrm{N}=6,961)$. 


\begin{tabular}{|c|c|c|c|c|c|c|c|c|c|c|}
\hline \multirow[t]{2}{*}{ Variables } & \multirow[t]{2}{*}{ n (\%) } & \multicolumn{3}{|c|}{ GAD, n (\%) } & \multicolumn{3}{|c|}{$\begin{array}{c}\text { Depressive symptoms, } \mathrm{n} \\
\text { (\%) }\end{array}$} & \multicolumn{3}{|c|}{ Poor sleep quality, n (\%) } \\
\hline & & No & Yes & $\chi^{2}$ & No & Yes & $\chi^{2}$ & No & Yes & $\chi^{2}$ \\
\hline Total & $\begin{array}{r}6961 \\
(100.0)\end{array}$ & $\begin{array}{r}4552 \\
(65.4)\end{array}$ & $\begin{array}{r}2409 \\
(34.6)\end{array}$ & & $\begin{array}{r}5624 \\
(80.8)\end{array}$ & $\begin{array}{r}1337 \\
(19.2)\end{array}$ & - & $\begin{array}{r}5687 \\
(81.7)\end{array}$ & $\begin{aligned} 1274 \\
(18.3)\end{aligned}$ & \\
\hline Gender & & & & $29.81^{* * *}$ & & & $26.05^{* * *}$ & & & 1.69 \\
\hline $\begin{array}{l}\text { Male } \\
\text { Female }\end{array}$ & $\begin{array}{r}3188 \\
(45.8) \\
3773\end{array}$ & $\begin{array}{r}2228 \\
(69.9) \\
2403\end{array}$ & $\begin{array}{r}960 \\
(30.1) \\
1370\end{array}$ & & $\begin{array}{r}2700 \\
(84.7) \\
3033\end{array}$ & $\begin{array}{r}488 \\
(15.3) \\
740\end{array}$ & & $\begin{array}{r}2579 \\
(80.9) \\
3098\end{array}$ & $\begin{array}{r}609 \\
(19.1) \\
675\end{array}$ & \\
\hline $\begin{array}{l}\text { Age (Year, } \\
\text { Mean } \pm \text { SD) }\end{array}$ & $\begin{array}{r}(54.2) \\
36.2 \pm 4.9\end{array}$ & (63.7) & (36.3) & $21.38^{* * *}$ & (80.4) & (19.6) & $11.94^{* *}$ & $(82.1)$ & (17.9) & 0.11 \\
\hline $\begin{array}{l}<35 \\
\geq 35\end{array}$ & $\begin{array}{r}2880 \\
(41.4) \\
4081 \\
(58.6)\end{array}$ & $\begin{array}{r}1779 \\
(61.8) \\
2740 \\
(67.1)\end{array}$ & $\begin{array}{r}1101 \\
(38.2) \\
1341 \\
(32.9)\end{array}$ & & $\begin{array}{r}2249 \\
(78.1) \\
3324 \\
(81.5)\end{array}$ & $\begin{array}{r}631 \\
(21.9) \\
757 \\
(18.5)\end{array}$ & & $\begin{array}{r}2351 \\
(81.6) \\
3344 \\
(81.9)\end{array}$ & $\begin{array}{r}529 \\
(18.4) \\
737 \\
(18.1)\end{array}$ & \\
\hline $\begin{array}{l}\text { Occupation } \\
\text { Healthcare }\end{array}$ & 2241 & 1445 & $(355)$ & 0.32 & 1793 & 448 & 1.51 & 1707 & $\begin{array}{r}534 \\
(238)\end{array}$ & $101.74^{* * *}$ \\
\hline $\begin{array}{l}\text { workers }^{\mathrm{a}} \\
\quad \text { Enterprise or } \\
\text { institution } \\
\text { workers }^{b}\end{array}$ & $\begin{array}{r}(32.2) \\
1792 \\
(25.7)\end{array}$ & $\begin{array}{r}(64.5) \\
1170 \\
(65.3)\end{array}$ & $\begin{array}{r}(35.5) \\
622 \\
(34.7)\end{array}$ & & $\begin{array}{r}(80.0) \\
1428 \\
(79.7)\end{array}$ & $\begin{array}{r}(20.0) \\
364 \\
(20.3)\end{array}$ & & $\begin{array}{r}(76.2) \\
1564 \\
(87.3)\end{array}$ & $\begin{array}{r}(23.8) \\
228 \\
(12.7)\end{array}$ & \\
\hline $\begin{array}{l}\text { Teachers } \\
\text { students }^{\mathrm{c}}\end{array}$ & $\begin{array}{r}1402 \\
(20.1)\end{array}$ & $\begin{array}{r}911 \\
(65.0)\end{array}$ & $\begin{array}{r}491 \\
(35.0)\end{array}$ & & $\begin{array}{r}1106 \\
(78.9)\end{array}$ & $\begin{array}{r}296 \\
(21.1)\end{array}$ & & $\begin{array}{r}1204 \\
(85.9)\end{array}$ & $\begin{array}{r}198 \\
(14.1)\end{array}$ & \\
\hline Others ${ }^{\mathrm{d}}$ & $\begin{array}{r}1526 \\
(22.0)\end{array}$ & $\begin{array}{r}993 \\
(65.1)\end{array}$ & $\begin{array}{r}533 \\
(34.9)\end{array}$ & & $\begin{array}{r}1231 \\
(80.7)\end{array}$ & $\begin{array}{r}295 \\
(19.3)\end{array}$ & & $\begin{array}{r}1228 \\
(80.5)\end{array}$ & $\begin{array}{r}298 \\
(19.5)\end{array}$ & \\
\hline $\begin{array}{l}\text { Times spent } \\
\text { focusing on the } \\
\text { COVID-19 } \\
\text { pandemic }\end{array}$ & & & & $78.03^{* * *}$ & & & $21.84^{* * *}$ & & & $16.21^{* * *}$ \\
\hline $\begin{array}{l}<1 \text { hour/day } \\
1-2 \text { hours/day } \\
\geq 3 \text { hours/day }\end{array}$ & $\begin{array}{r}1324 \\
(19.0) \\
2605 \\
(37.4) \\
3032 \\
(43.6)\end{array}$ & $\begin{array}{r}919 \\
(69.4) \\
1842 \\
(70.7) \\
1825 \\
(60.2)\end{array}$ & $\begin{array}{r}405 \\
(30.6) \\
763 \\
(29.3) \\
1207 \\
(39.8)\end{array}$ & & $\begin{array}{r}1062 \\
(80.2) \\
2204 \\
(84.6) \\
2429 \\
(80.1)\end{array}$ & $\begin{array}{r}262 \\
(19.8) \\
401 \\
(15.4) \\
603 \\
(19.9)\end{array}$ & & $\begin{array}{r}1098 \\
(82.9) \\
2180 \\
(83.7) \\
2417 \\
(79.7)\end{array}$ & $\begin{array}{r}226 \\
(17.1) \\
425 \\
(16.3) \\
615 \\
(20.3)\end{array}$ & \\
\hline $\begin{array}{l}\text { Knowledge of the } \\
\text { COVID-19 }\end{array}$ & & & & $16.85^{* * *}$ & & & $15.62^{* * *}$ & & & $7.49^{*}$ \\
\hline $\begin{array}{l}\text { Not } \\
\text { knowledgeable } \\
\text { General } \\
\text { knowledgeable } \\
\text { Knowledgeable }\end{array}$ & $\begin{array}{r}398 \\
(5.7) \\
1121 \\
(16.1) \\
5442 \\
(78.2) \\
\end{array}$ & $\begin{array}{r}242 \\
(60.7) \\
791 \\
(70.6) \\
3543 \\
(65.1) \\
\end{array}$ & $\begin{array}{r}156 \\
(39.3) \\
330 \\
(29.4) \\
1899 \\
(34.9) \\
\end{array}$ & & $\begin{array}{r}327 \\
(82.1) \\
963 \\
(85.9) \\
4403 \\
(80.9) \\
\end{array}$ & $\begin{array}{r}71 \\
(17.9) \\
158 \\
(14.1) \\
1039 \\
(19.1) \\
\end{array}$ & & $\begin{array}{r}327 \\
(82.1) \\
949 \\
(84.7) \\
4419 \\
(81.2) \\
\end{array}$ & $\begin{array}{r}71 \\
(17.9) \\
172 \\
(15.3) \\
1023 \\
(18.8) \\
\end{array}$ & \\
\hline
\end{tabular}




\begin{tabular}{|c|c|c|c|c|c|c|}
\hline \multirow[t]{2}{*}{ les } & \multicolumn{2}{|c|}{ GAD } & \multicolumn{2}{|c|}{ Depressive symptoms } & \multicolumn{2}{|c|}{ Poor sleep quality } \\
\hline & $\begin{array}{l}O R \\
C I)\end{array}$ & $\begin{array}{l}A O R \\
C I)\end{array}$ & $\begin{array}{l}O R \quad(95 \% \\
C I)\end{array}$ & $\begin{array}{l}A O R \\
C I)\end{array}$ & $\begin{array}{l}O R^{2} \\
C I)\end{array}$ & $\begin{array}{l}A O R \quad(95 \% \\
C I)\end{array}$ \\
\hline \multicolumn{7}{|l|}{$\mathrm{r}$} \\
\hline 3 & 1.00 & 1.00 & 1.00 & 1.00 & 1.00 & 1.00 \\
\hline ale & $\begin{array}{l}1.33(0.91- \\
1.93)\end{array}$ & $\begin{array}{l}1.24 \\
1.63)\end{array}(0.85-$ & $\begin{array}{l}1.35(0.84- \\
2.17)\end{array}$ & $\begin{array}{l}1.28(0.79- \\
2.08)\end{array}$ & $\begin{array}{l}0.92(0.59- \\
1.44)\end{array}$ & $\begin{array}{l}0.84(0.53- \\
1.33)\end{array}$ \\
\hline ; years & $\begin{array}{l}1.57(1.32- \\
2.05)^{* * *}\end{array}$ & $\begin{array}{l}1.45(1.29- \\
2.01)^{* * *}\end{array}$ & $\begin{array}{l}1.70(1.31- \\
2.19)^{* * *}\end{array}$ & $\begin{array}{l}1.67(1.44- \\
2.12)^{* * *}\end{array}$ & $\begin{array}{l}0.72(0.46- \\
1.11)\end{array}$ & $\begin{array}{l}0.67(0.41- \\
1.10)\end{array}$ \\
\hline $\begin{array}{l}\text { j years } \\
\text { ation }\end{array}$ & 1.00 & 1.00 & 1.00 & 1.00 & 1.00 & 1.00 \\
\hline thcare workers $^{\mathrm{a}}$ & $\begin{array}{l}1.32 \\
2.06)\end{array}(0.84-$ & $\begin{array}{l}1.32 \\
2.12)\end{array}$ & $\begin{array}{l}1.19(0.68- \\
2.06)\end{array}$ & $\begin{array}{l}1.06(0.60- \\
1.89)\end{array}$ & $\begin{array}{l}1.51(1.18- \\
2.12)^{* * *}\end{array}$ & $\begin{array}{l}1.40(1.16- \\
1.91)^{* * *}\end{array}$ \\
\hline $\begin{array}{l}\text { rpprise or institution } \\
\mathrm{s}^{\mathrm{b}}\end{array}$ & $\begin{array}{l}0.86(0.53- \\
1.41)\end{array}$ & $\begin{array}{l}0.91 \\
1.52)\end{array}$ & $\begin{array}{l}0.83(0.45- \\
1.53)\end{array}$ & $\begin{array}{l}0.84(0.45- \\
1.56)\end{array}$ & $\begin{array}{l}0.62(0.34- \\
1.15)\end{array}$ & $\begin{array}{l}0.62(0.33- \\
1.15)\end{array}$ \\
\hline 'hers or students ${ }^{\mathrm{c}}$ & $\begin{array}{l}1.78(1.03- \\
3.07)^{*}\end{array}$ & $\begin{array}{l}1.65(0.91- \\
2.02)\end{array}$ & $\begin{array}{l}1.48(0.77- \\
2.84)\end{array}$ & $\begin{array}{l}1.14(0.56- \\
2.01)\end{array}$ & $\begin{array}{l}0.76(0.38- \\
1.56)\end{array}$ & $\begin{array}{l}0.96(0.45- \\
2.08)\end{array}$ \\
\hline $\begin{array}{l}\text { ers }^{\mathrm{d}} \\
\text { spent focusing on the }\end{array}$ & 1.00 & 1.00 & 1.00 & 1.00 & 1.00 & 1.00 \\
\hline \multicolumn{7}{|l|}{ )-19 pandemic ${ }^{\mathrm{e}}$} \\
\hline lour/day & 1.00 & 1.00 & 1.00 & 1.00 & 1.00 & 1.00 \\
\hline hours/day & $\begin{array}{l}0.94 \\
1.55)\end{array}$ & $\begin{array}{l}0.97 \\
1.62)\end{array}$ & $\begin{array}{l}0.74(0.40- \\
1.34)\end{array}$ & $\begin{array}{l}0.75(0.41- \\
1.38)\end{array}$ & $\begin{array}{l}0.95(0.51- \\
1.75)\end{array}$ & $\begin{array}{l}0.87(0.46- \\
1.62)\end{array}$ \\
\hline lours/day & $\begin{array}{l}1.95(1.67- \\
2.41)^{* * *}\end{array}$ & $\begin{array}{l}1.68(1.43- \\
2.15)^{* * *}\end{array}$ & $\begin{array}{l}1.01(0.58- \\
1.76)\end{array}$ & $\begin{array}{l}1.11(0.62- \\
1.98)\end{array}$ & $\begin{array}{l}1.23(0.69- \\
2.20)\end{array}$ & $\begin{array}{l}1.09(0.60- \\
1.98)\end{array}$ \\
\hline \multicolumn{7}{|l|}{ edge of the COVID-19 } \\
\hline knowledgeable & 1.00 & 1.00 & 1.00 & 1.00 & 1.00 & 1.00 \\
\hline eral knowledgeable & $\begin{array}{l}0.64 \\
1.57)\end{array}(0.26-$ & $\begin{array}{l}0.55(0.23- \\
1.38)\end{array}$ & $\begin{array}{l}0.76(0.24- \\
2.37)\end{array}$ & $\begin{array}{l}0.64(0.20- \\
2.05)\end{array}$ & $\begin{array}{l}0.83(0.27- \\
2.58)\end{array}$ & $\begin{array}{l}0.75(0.24- \\
2.35)\end{array}$ \\
\hline wledgeable & $\begin{array}{l}0.83(0.38- \\
1.81)\end{array}$ & $\begin{array}{l}0.64(0.28- \\
1.44)\end{array}$ & $\begin{array}{l}1.08(0.40- \\
2.93)\end{array}$ & $\begin{array}{l}0.84(0.30- \\
2.35)\end{array}$ & $\begin{array}{l}1.07(0.40- \\
2.89)\end{array}$ & $\begin{array}{l}0.98(0.35- \\
2.73)\end{array}$ \\
\hline
\end{tabular}

Abbreviations: GAD, generalized anxiety disorder; OR, odds ratio; $A O R$, adjusted odds ratio; $95 \% C I$, 95\% confidence interval; COVID-19, 2019 Corona Virus Disease.

ancluded doctors, nurses and health administrators.

${ }^{\mathrm{b}}$ Included enterprise employees, national/provincial/municipal institution workers and other relevant staff.

${ }^{\mathrm{c}}$ Included teachers or students from universities, middle schools, or elementary schools.

${ }^{\mathrm{d}}$ Includer freelancers, retiree, social worker and other relevant staff.

${ }^{\mathrm{e}}$ Average time spent focusing on the COVID-19 pandemic information each day

${ }^{*} P<0.05,{ }^{* * *} P<0.001$. 